\title{
Drying of Poultry Manure for Use as Animal Feed
}

\author{
A.E. Ghaly and K.N. MacDonald \\ Department of Process Engineering and Applied Science, Dalhousie University, Halifax, Canada
}

Received 2012-06-14, Revised 2012-07-03; Accepted 2012-07-03

\begin{abstract}
The poultry industry is one of the largest and fastest growing sectors of livestock production in the world. The estimated 2010 world flock was over 18 billion birds with a yearly manure output of 22 million tonnes. Storage and disposal of raw poultry manure have become an environmental problem because of the associated air, water and soil pollution. Environmental and health problems such as odor and pathogens that may arise during and after land application of raw manure can be eliminated by drying. Dried manure can be utilized as a feed for ruminants because of its high nitrogen content. The aim of this study was to investigate the effects of drying temperature and depth, as well as the nutritional profile of dried manure and its suitability as an animal feed. Dried poultry manure contained sufficient levels of digestible energy, crude fiber, crude protein, crude fat, cobalt and iodine. Although dried poultry manure did not meet the dietary requirements for calcium, chloride, magnesium, phosphorus, potassium, sodium, copper, iron, manganese, selenium, sulfur or zinc it could be used as a feed stuff for ruminants after supplementation with the required nutrients. Heated air drying was most efficient at $60^{\circ} \mathrm{C}$ and at a depth of $3 \mathrm{~cm}$. During drying poultry manure decreased in $\mathrm{pH}$ (8.4-6.9), protein content (43 to 39-43\%) and amino acid content. The greatest reductions in microbial population occurred at the highest temperature $\left(60^{\circ} \mathrm{C}\right)$ and the lowest manure depth $(1 \mathrm{~cm})$. Reductions in the number of bacteria, mold/yeast and E. coli were 65-99, 74-99 and 99.97\% respectively, Salmonellae was not detected in the dried product. Dried poultry manure was found to have a non-offensive odor. Odor intensity and offensiveness were reduced by 65 and $69 \%$ respectively during drying. Thin layer heated air drying of poultry manure between 40 and $60^{\circ} \mathrm{C}$ created a safe and nutritionally appropriate feed for ruminants.
\end{abstract}

Keywords: Poultry Manure, Drying, Temperature, Depth, Moisture Content, Pathogens, Odor, Protein, Amino Acid, Minerals, Animal Feed

\section{INTRODUCTION}

The poultry industry is one of the largest and fastest growing sectors of livestock production in the world with a $35 \%$ increase in meat and egg production in the period from 2000-2008 (FAO, 2010). Rearing of birds has grown from a side-line occupation into a commercial enterprise with single farms housing thousands of birds. The 2010 world annual census data, estimated the world flock to be over 18 billion birds with an estimated yearly output of 22 million tonnes of manure (FAO, 2010). This rapid expansion of the industry over the last several decades has increased the need to find economically viable and environmentally acceptable ways of utilizing such large quantities of waste.

With increasing production of poultry products, storage and disposal of raw poultry manure has become an environmental problem due to the associated air, water and soil pollution (Benali and Kudra, 2002). Poultry manure begins to decompose immediately after excretion giving off ammonia which, in high concentrations, can have adverse effects on the health and productivity of birds as well as the health of the farm workers (Zhang and Lau, 2007; Amon et al., 2006). Manure can also serve as a breeding ground for pathogenic microorganisms and as a medium for diseases transmission among birds. Flies and other undesirable insects can breed on the manure leading to the health hazards and nuisances associated with them (Lay et al., 2011; Axtell, 1999). Manure is also a source of odor caused by the activity of anaerobic microorganisms in the manure (Berry and Miller, 2005; Fares et al., 2005). It is, therefore, necessary to subject poultry manure to some treatments in order to improve its storage and handling properties and to minimize the risk of disease transmission and environmental pollution. 
Proper poultry manure management systems that will preserve the environment, contribute to both animal and human health and return a profit on investment to farmers need to be developed.

Poultry manure can be dried and used in animal feeding. Drying refers to the removal of moisture from the manure so that it is near equilibrium with atmospheric air. By drying, the rate of deterioration from chemical and biological activity is minimized and the environmental problems associated with raw manure can be prevented. Drying also removes manure stickiness and hence allows for easier handling (Bernhart and Fasina, 2009). Drying with heated air offers a number of advantages over unheated air drying including a higher rate of oxidation and pathogen destruction (Loehr, 1977). Drying with heated air can be carried out using a variety of heat sources such as solar energy, electricity, natural gas or other fossil fuels. However solar energy offers several advantages over other energy sources: (a) it is available in abundance all year round, (b) it has higher rate of oxidation and (c) it results in good waste stabilization, odor control and pathogen destruction (ASABE, 2009; Amine-Khodja et al., 2006; Martens and Bohm, 2009).

Dried poultry manure has been used as an animal feed for ruminants (Thomas et al., 1972; Alam et al., 2008). The use of poultry manure as cattle feed could significantly improve the economics of dairy and beef production. Savings in feed cost through nutrient recycling would be sufficient to justify the cost of drying while also protecting the environment. However the question of pathogen transmission from manure to animals must be addresses (Boer, 1981).

The main aim of this study was to evaluate the effects of manure drying on the suitability of dried manure for use as an animal feed. The specific objectives were to (a) evaluate the drying behaviour of laying hen manure at temperatures in the range of $40-60^{\circ} \mathrm{C}$ and depths of manure between 1 and $3 \mathrm{~cm}$ and (b) determine the changes in the properties of the manure due to the drying process as measured by its nutritional value, pathogens content and presence and offensiveness of odor.

\section{MATERIALS AND METHODS}

\subsection{Drying Trays}

Three sets of trays, each set consisting of three trays of the same dimensions were constructed using galvanized metal sheets for the drying of poultry manure in the laboratory. The trays each had a drying surface areas of $100 \mathrm{~cm}^{2}$. The depths of the trays were $1 \mathrm{~cm}, 2$ $\mathrm{cm}$ and $3 \mathrm{~cm}$ for sets 1, 2 and 3, respectively. Figure 1 shows the dimensions of the drying trays.

\subsection{Manure}

Poultry manure was obtained from a layer house on Archibald Farms located in Stewiack East, approximately $80 \mathrm{~km}$ from Halifax, Nova Scotia. The manure was collected from under the battery cages of a laying house accommodating approximately 50,000 hens. The manure collected was fresh and was not subjected to any treatment on the farm. It was placed in clean plastic bags and transported to the Waste Management Laboratory at Dalhousie University, Halifax, Nova Scotia where it was stored at $-18^{\circ} \mathrm{C}$. Some characteristics of the poultry manure used in this study are presented in Table 1.

\subsection{Experimental Procedure}

The effects of three drying temperatures (40,50 and $60^{\circ} \mathrm{C}$ ) and three manure depths $(1,2$ and $3 \mathrm{~cm})$ on the manure drying rate, drying time and manure characteristics were investigated. The selected temperature range is within the range $\left(35-75^{\circ} \mathrm{C}\right)$ of heated air using solar dryers (El-Sayed, 1993). Prior to placing the manure in the drying trays, it was removed from the freezer and allowed to thaw for $24 \mathrm{~h}$ at room temperature $\left(22^{\circ} \mathrm{C}\right)$. The three sets of trays were weighed using a digital scale (METTLER Balance model PM4600, Fisher Scientific, Montreal, Quebec). The trays were then filled to their respective depths with the manure and weighed again.

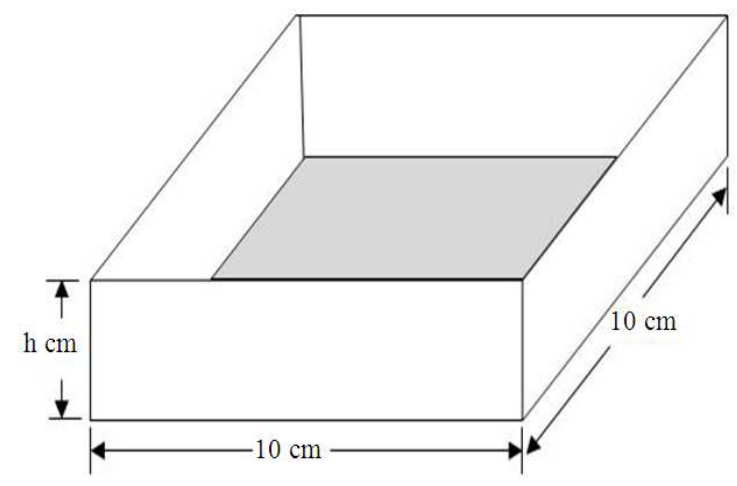

Fig. 1. The dimensions of the drying tray $(\mathrm{h}=1,2$, or $3 \mathrm{~cm})$.

Table 1. Some characteristics of the poultry manure used in the study.

\begin{tabular}{ll}
\hline Item & Measured value \\
\hline Moisture content & $78.4 \%$ \\
Density & $960 \mathrm{~kg} / \mathrm{m}^{3}$ \\
Total solids & $215520 \mathrm{mg} / \mathrm{L}$ \\
Volatile solids & $139770 \mathrm{mg} / \mathrm{L}$ \\
Ash & $75750 \mathrm{mg} / \mathrm{L}$ \\
Total Chemical Oxygen Demand & $328500 \mathrm{mg} / \mathrm{L}$ \\
Soluble Chemical Oxygen Demand & $130000 \mathrm{mg} / \mathrm{L}$ \\
Total Kjeldahl Nitrogen & $18960 \mathrm{mg} / \mathrm{L}$ \\
Ammonium Nitrogen & $9470 \mathrm{mg} / \mathrm{L}$ \\
Calcium & $19760 \mathrm{mg} / \mathrm{L}$ \\
Phosphorous & $5590 \mathrm{mg} / \mathrm{L}$ \\
Potassium & $4140 \mathrm{mg} / \mathrm{L}$ \\
pH & 8.40 \\
\hline
\end{tabular}


The filled trays were placed in a forced draft oven (Isotemp Oven Model 655F, Fisher Scientific, Montreal, Quebec) adjusted to the required temperature. The drying rate was monitored by determining the change in weight at $2 \mathrm{~h}$ time intervals until a constant weight was reached. The oven temperature was then readjusted to the next required temperature and the same experimental procedure was followed. Three replicates for each temperature-manure depth combination were carried out.

\subsection{Experimental Analysis}

The moisture content, density, total and volatile solids, total and soluble chemical oxygen demand, total-Kjeldahl and ammonium nitrogen, elemental (P, K, Ca) and $\mathrm{pH}$ analyses were performed on the raw manure. The moisture content, $\mathrm{pH}$, protein, amino acids profile (12 amino acids), minerals, total plate count, pathogen, insect and odor analyses were performed on the dried samples. The density, total solids and chemical oxygen demand analyses were preformed according to the procedures described in the Standard Methods for examination of water and waste water (APHA, 1980). The total Kjeldahl and ammonium nitrogen analyses were performed using the Kjeltec Auto Analyzer (Model 1030, Toecator, Hoganas, Sweeden) according to the Kjeldahl method. The $\mathrm{pH}$ was measured using a $\mathrm{pH}$ meter (Model 805MV, Fisher Scientific, Montreal, Quebec) according to the procedure described in the Methods of Soil Analysis (ASABE, 2009). The nutritional analyses (energy, carbohydrates, crude protein, crude fat and crude fiber) were performed by Maxxam Analytics Inc., Mississauga, Ontario according to the procedure described by AOAC (2011). The elemental analyses (Ca, Cl, Mg, K, P, Na, S, B, Cu, Fe, Mn, Mo, Se and Zn) were performed in the Mineral Engineering Centre of Dalhousie University, Halifax, Nova Scotia, using flame atomic absorption spectroscopy. The moisture content, protein, amino acid profiles, microbial and insect and odor analyses were performed as follows.

\subsubsection{Moisture Content}

The moisture content was determined using the oven drying method according to the procedure described in the ASAE standards (ASABE, 2009). Samples of approximately $10 \mathrm{~g}$ were dried at $103^{\circ} \mathrm{C}$ for $24 \mathrm{~h}$ in a drying oven (Isotemp Oven Model 655F, Fisher Scientific, Montreal, Quebec) and the Moisture Contents (MC) were calculated on both wet basis (\% wb) and dry basis $(\% \mathrm{db})$ as follows:

$$
\begin{aligned}
& \mathrm{MC}(\% \mathrm{wb})=\frac{(\text { Weight of wet sample }- \text { Weight of dry sample }) \times 100}{\text { Weight of wet sample }} \\
& \mathrm{MC}(\% \mathrm{db})=\frac{(\text { Weight of wet sample }- \text { Weight of dry sample }) \times 100}{\text { Weight of dry sample }}
\end{aligned}
$$

\subsubsection{Odor}

An organoleptic test developed for the measurement of odor from animal waste was used to measure the presence and offensiveness of odor in the dried poultry manure (Ghaly and MacDonald, 2012). This method was chosen because the complex nature of manure odor is best judged by the human nose. In this test, scales of $0-10$ were used to rate the odor as to its presence and offensiveness. No odor was assigned a score of 0 and very strong odor was assigned a score of 10 . A scale of no offensive odor (0) and very offensive odor (10) was also used. The intermediate numbers 1-9 are described in the score sheet (Fig. 2), which was used by the panel members to rate the samples $(50 \mathrm{~g})$ placed before them in $125 \mathrm{~mL}$ Erlenmeyer flasks. They were asked to rate the contents of the flasks according to the scales $0-10$. The lower limits $(0)$ were assigned to distilled water, whereas the upper limits (10) were assigned to the fresh poultry manure. The odor testing panel consisted of technicians, graduate and undergraduate students and faculty. The size of the panel was 10 members. Each panel member was asked to rate the samples as to the presence of odor and the odor offensiveness according to the 0-10 scales and to describe the odor on a separate data sheet.

\subsubsection{Total Microbial Count}

Total plate count was employed to estimate the numbers of viable aerobic and facultative microorganisms based on the assumption that each viable cell would develop into a colony after incubation. The manure samples were collected in wide mouth sterilized containers. Each sample was diluted to insure that one of the final plates would have 30-300 colonies (the range which allows the most accurate approximation of the microbial population). The initial dilution (1:10) was prepared by placing $1 \mathrm{~g}$ on manure into $10 \mathrm{~mL}$ of physiological saline water. The bottle was shaken vigorously to obtain a uniform distribution of organisms. Further dilutions $\left(1: 10^{3}, 1: 10^{4}, 1: 10^{5}, 1: 10^{7}\right.$ and $\left.1: 10^{8}\right)$ were made by pipetting measured aliquots into physiological saline water. The bottles were thoroughly shaken and $1 \mathrm{~mL}$ of the dilution were pipetted into each labeled (specimen and dilution) petri dish. Samples from each dilution were plated in duplicate. Approximately 15 $\mathrm{mL}$ of cooled melted medium was poured into each petri dish. Immediately thereafter, the plates were gently rotated 6 times in each direction to distribute the inoculum throughout the medium. The plates were allowed to solidify and incubated in the inverted position in an incubator (Model Number 2020, VWR International, Cornelius, Oregon) at $35-37^{\circ} \mathrm{C}$ for $48 \mathrm{~h}$. 
Plates that contained 30-300 colonies were selected for counting. An accurate count of the colonies was made by placing the plates on the platform of a colony counter (Cat.No.7-910, Fisher Scientific, Montreal, Quebec). This instrument facilitated the counting process since the colonies were illuminated and seen against a ruled background. The number of colonies was counted and the dilution of the specimen were used to calculate the cell count per milliliter of the specimen.

\subsubsection{Microbial and Insect Analyses}

The following analyses were also performed on the raw and dried manure samples: (a) yeast and mold enumeration (b) E. Coli estimation (c) Salmonellae examination (d) microscopic examination of insect, flies eggs and parasite. These analyses were performed at Nova Scotia Research Foundation Corporation, Dartmouth, Canada.

Name:

Date:

A. Rate the samples to the presence of odor and the odor as to offensiveness according to the following scale using samples " 0 " as having 0 rating and samples " 10 " as having 10 rating.

\begin{tabular}{lclc}
\hline \multicolumn{1}{c}{ Presence } & \multicolumn{2}{c}{ Offensiveness } \\
\hline No odor & 0 & No offensive odor & 0 \\
Very faint & $1-2$ & Very faint offensive odor & $1-2$ \\
Faint & $3-4$ & Faint offensive odor & $3-4$ \\
Definite & $5-7$ & Definite offensive odor & $5-7$ \\
Strong & $8-9$ & Strong offensive odor & $8-9$ \\
Very strong & 10 & Very strong offensive odor & 10 \\
\hline
\end{tabular}

B. Describe the odor of each sample by giving an appropriate descriptive term. Possible terms that might be used are given in the list below or you may use a term of your choice which you feel properly describes the odor.

Mold, musty
Fish
Stagnant water
Sulfide, rotten eggs
Petroleum
Earth

Yeast

Ammonia

Grain, animal feed

Sour, fermented

Rotten cabbage, mercaptans

Other (Please specify)

\section{RATING}

\begin{tabular}{cccc}
\hline Sample & $\begin{array}{c}\text { Presence } \\
\text { Rating }\end{array}$ & $\begin{array}{c}\text { Offensiveness } \\
\text { Rating }\end{array}$ & $\begin{array}{c}\text { Odor } \\
\text { Description }\end{array}$ \\
\hline 1 & & \\
\hline 3 & & \\
\hline
\end{tabular}

Thank you for your time

Fig. 2. Odor evaluation sheet (Ghaly and MacDonald, 2012). 


\subsubsection{Protein}

The total protein content was determined using the Tecator Kjeltec Auto Analyzer (Model-1026, Fisher Scientific, Montreal, Quebec). Clean empty tarred beakers were weighed $\left(\mathrm{W}_{1}\right)$ and approximately $1.0 \mathrm{~g}$ of the manure samples (or about $0.5 \mathrm{~g}$ of dried samples) were placed in each of the beakers and reweighed $\left(\mathrm{W}_{2}\right)$. The contents of each of the beakers were transferred to macro $250 \mathrm{~mL}$ digestion tubes. One "Kjeltab" (containing $3.5 \mathrm{~g}$ $\mathrm{K}_{2} \mathrm{SO}_{4}$ and. $0.0035 \mathrm{~g} \mathrm{Se}$ ), $3.0 \mathrm{~mL}$ of distilled water $\left(\mathrm{H}_{2} \mathrm{O}\right), 0.6 \mathrm{~mL}$ of concentrated sulphuric acid $\left(\mathrm{H}_{2} \mathrm{SO}_{4}\right)$ and $0.3 \mathrm{~mL}$ of $30 \%$ hydrogen peroxide $\left(\mathrm{H}_{2} \mathrm{O}_{2}\right)$ was added to the samples in the digestion tubes. The samples were digested at $420^{\circ} \mathrm{C}$ for $30 \mathrm{~min}$ in a digestion block heater (Tecator Digester Sytem, 20 Model-1016, Fisher Scientific, Montreal, Quebec). The digestion tubes were removed and allowed to cool for $10 \mathrm{~min}$. Then, $30 \mathrm{~mL}$ of distilled water was added to the digestion tubes. The test tubes and digests were transferred to the Auto Analyzer. The constants, $\mathrm{A}$ and $\mathrm{B}$, for the equipment were set at 0.00 and 1.862 , respectively. The titrant acid and the predetermined blank sample were set at $0.2127 \mathrm{M}$ and 0.01 , respectively. Distillations, titrations and calculations were performed automatically. The percentage protein was computed from the following equation:

$$
\text { Total protein }(\%)=\frac{\text { Displayed results }}{\mathrm{W}_{2}-\mathrm{W}_{1}}
$$

\subsubsection{Amino Acids Profile}

The amino acid contents (alanine, glutamic, threonine, argninine, phenylalamine, valine, methionine, histidine, serine, leucine, lysine and cystine) were determined using the HFB-IBA (Heptafluorobutyric isobutyl esters of amino acids) Amino Acid Derivatization Kit (Alltech Associates, Inc. Cat. No.18094). First, $50 \mathrm{mg}$ samples of manure were weighed using a Mettler automatic scale (Model AE200, Fisher Scientific, Montreal, Quebec) and placed in small reaction vials. $3 \mathrm{~mL}$ of 0.2 $\mathrm{M} \mathrm{HCl}$ was added to each vial and the solutions were heated to approximately $110^{\circ} \mathrm{C}$ for $30 \mathrm{~h}$ using a block heater (Model 16500-10, Hach Chemical Co., loveland, $\mathrm{CO})$. Then, the vials were removed from the heater and dried under a stream of dry nitrogen. $1.25 \mathrm{~mL}$ of acetyl chloride (Cat. No. 18094B, Alltech Associates Inc. Deerfield, Illinois) was slowly added to $50 \mathrm{~mL}$ of isobutanol and the mixture was added to each vial, (which contained dried sample). The vials were capped and heated at $110^{\circ} \mathrm{C}$ for $45 \mathrm{~min}$ then uncapped and heated at $115^{\circ} \mathrm{C}$ under stream of dry nitrogen to remove excess reagent. The vials were removed from the heater and cooled in an ice bath for approximately $5 \mathrm{~min} .3 \mathrm{~mL}$ of methylene chloride and $2 \mathrm{~mL}$ of HFBA (Cat. No.18094A, Alltech Associates Inc. Deerfield, Illinois) were added to each vial. The vials were capped and heated at $100^{\circ} \mathrm{C}$ for $4 \mathrm{~h}$. The vials were removed from the heater and, after cooling to ambient temperature, excess reagent was again evaporated under a stream of dry nitrogen. The dried samples were redissolved in 2 $\mathrm{mL}$ of ethyl acetate and injected into the gas chromatograph (Model-HP5890 Series II, Hewlett, Palo Alto, CA). The amino acids were determined from the output results of the gas chromatograph.

\section{RESULTS AND DISCUSSION}

\subsection{Drying Time}

Table 2 shows the drying times at various manure depths and drying temperatures. The results indicated that the $1 \mathrm{~cm}$ deep manure layer dried the fastest at all three drying temperatures, followed by the $2 \mathrm{~cm}$ deep manure layer and the $3 \mathrm{~cm}$ deep layer. The thinner the manure layer, the lower the amount of moisture it contained and consequently the shorter the time required to drive off the moisture. The times required to dry the $2 \mathrm{~cm}$ deep manure layer at the temperatures of for 40,50 and $60^{\circ} \mathrm{C}$ were more than the time required to dry the $1 \mathrm{~cm}$ deep manure layer by about 106, 100 and $87 \%$ while the times required to dry the $3 \mathrm{~cm}$ deep manure layer were more than the times required to dry the $2 \mathrm{~cm}$ deep manure layer by 22 , 12 and $7 \%$, respectively.

Table 2. Drying time and drying effectiveness of poultry manure.

\begin{tabular}{lllllll}
\hline $\begin{array}{l}\text { Drying } \\
\text { Temperature }\left({ }^{\circ} \mathrm{C}\right)\end{array}$ & $\begin{array}{l}\text { Drying } \\
\text { Depth }(\mathrm{cm})\end{array}$ & $\begin{array}{l}\text { Drying } \\
\text { Time }(\mathrm{h})\end{array}$ & $\begin{array}{l}\text { Weight }(\mathrm{g}) \\
\text { Initial }\end{array}$ & Final & $\begin{array}{l}\text { Moisture } \\
(\mathrm{g})\end{array}$ & $\begin{array}{l}\text { Drying Effectiveness } \\
(\mathrm{h} / \mathrm{g})\end{array}$ \\
\hline 40 & 1 & 55 & 125.95 & 27.15 & 98.80 & 0.56 \\
& 2 & 106 & 224.70 & 48.43 & 176.27 & 0.60 \\
50 & 3 & 120 & 312.72 & 67.41 & 245.31 & 0.50 \\
& 1 & 44 & 129.16 & 27.84 & 101.32 & 0.43 \\
60 & 2 & 94 & 226.21 & 48.71 & 177.50 & 0.47 \\
& 3 & 28 & 314.28 & 67.74 & 246.54 & 0.37 \\
& 1 & 127.18 & 27.41 & 99.77 & 0.28 \\
& 2 & 227.86 & 49.11 & 178.75 & 0.29 \\
\hline
\end{tabular}


Several researchers studied the effect of drying temperature on the drying rate of various materials and reported faster drying rates at higher temperatures. Leonard et al. (2005) investigated the effect of temperature $\left(120,140\right.$ and $\left.160^{\circ} \mathrm{C}\right)$ on the rate of drying of municipal sludge and reported the fastest rate of drying at $160^{\circ} \mathrm{C}$. Onider et al. (2010) studied the drying kinetics of rough rice at varying temperatures $\left(19-26^{\circ} \mathrm{C}\right)$ and relative humidity's (19-68\%) and observed the fastest drying rate at the highest temperature $\left(26^{\circ} \mathrm{C}\right)$. Panchariya et al. (2002) studied thin layer drying of black tea at various temperatures $\left(80-120^{\circ} \mathrm{C}\right)$ and air velocities and reported the fastest drying rate at the highest temperature $\left(120^{\circ} \mathrm{C}\right)$. Gely and Santalla (2007) studied the effects of initial moisture content and temperature $\left(50-90^{\circ} \mathrm{C}\right)$ on the drying rate of quinoa seeds and observed the highest drying rates at $90^{\circ} \mathrm{C}$. Brooks et al. (2008) investigated the effects of temperature $\left(55\right.$ and $\left.65^{\circ} \mathrm{C}\right)$ on the drying kinetics of tomato pieces of various geometries (whole, halves, quarters and eights) and found the fastest drying rates at $65^{\circ} \mathrm{C}$ for all geometries.

The effect of bed depth on drying rate was also investigated by several researchers. Nazghelichi et al. (2010) investigated the effect of bed depth (30,60 and 90 $\mathrm{mm}$ ) on the drying of carrot cubes and found the shortest drying time to be achieved at the $30 \mathrm{~mm}$ depth. Maskan et al. (2002) investigated the effect of layer thickness $(0.71-2.86 \mathrm{~mm})$ on the drying of fruit leather at various temperatures and air velocities and found the optimum depth to be $0.71 \mathrm{~mm}$. Ertekin and Yaldiz (2004) investigated the effect of eggplant slice thickness $(0.63,1.27$, $2.54 \mathrm{~cm}$ ) on drying and reported the fastest drying times with the $0.63 \mathrm{~cm}$ thick slices. These results are similar to those obtained in the present study.

\subsection{Drying Effectiveness}

The parameter "drying effectiveness" is defined in this study as the time required to drive off $1 \mathrm{~g}$ of moisture from the manure. The results obtained from the present study showed that the difference in drying time between the shallower and deeper manure layers decreased as the temperature increased. However, when considering the drying effectiveness, the $3 \mathrm{~cm}$ manure depth was superior at all temperatures as less time was required to remove $1 \mathrm{~g}$ of water from the manure (Fig. 3). The results also showed that more time was required to remove one gram of water from the manure at the $2 \mathrm{~cm}$ depth than those required at the 1 and $3 \mathrm{~cm}$ depths at all temperatures studied as shown in Fig. 3.

Ertekin and Yaldiz (2004) conducted a study into the thin layer drying of eggplant slices $(0.63,1.27$ and $2.54 \mathrm{~cm}$ thick) and found the most effective drying with $2.54 \mathrm{~cm}$ thick slices. Significant increases in the depth of bed have been reported to decrease drying effectiveness. Rao et al. (2007) investigated the thin layer drying of parboiled paddy at depths between 5 and $20 \mathrm{~cm}$ and reported optimum effectiveness with the lower depths in the range of 7-10 cm. Akal et al. (2007) investigated the effect of bed depth $(10-30 \mathrm{~cm})$ and air temperature (40, 50 and $60^{\circ} \mathrm{C}$ ) on the effectiveness of thin layer drying of rough rice and found the effectiveness to decrease with increasing bed depth. Nazghelichi et al. (2010) investigated the effect of bed depth $(30,60$ and $90 \mathrm{~mm})$ on the drying effectiveness of carrot cubes and found the optimum drying efficiency at $30 \mathrm{~mm}$ depth.

\subsection{Odor}

At the start of each experiment, the odor given off near the oven during the drying process was noticeable.

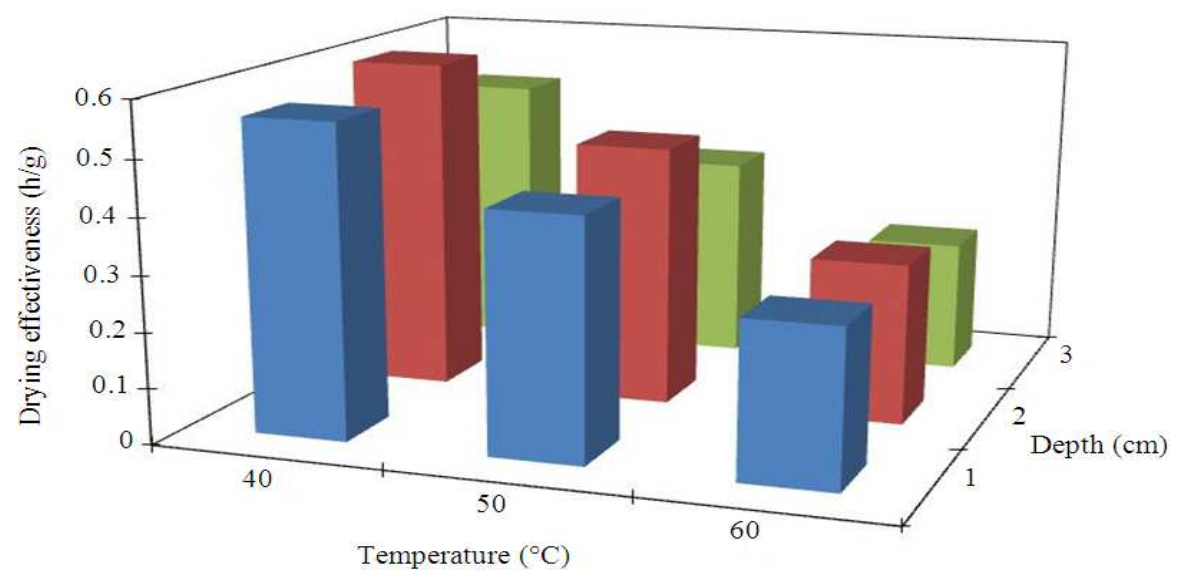

Fig. 3. Manure drying effectiveness. 
However, as the drying process progressed, the presence and offensiveness of the odor decreased with the time and the final product (dried manure) did not have any offensive odor. The result of the organoleptic test (Table 3 and Fig. 4) showed that both the presence and offensiveness of the odor in the dried poultry manure were reduced by $65.3 \%$ and $69.3 \%$ (as compared to that of the fresh poultry manure). The odor present in the dried manure was not found to be offensive $(23.3 \%$ of the panel members described the odor as that of grain, $20 \%$ described it as a mold musty, $13.3 \%$ described it as ammonia, $13.3 \%$ described it as sour, fermented, $6.7 \%$ described it as fish odor, $6.7 \%$ described it as yeast odor ad $6.7 \%$ described it as sulfide rotten eggs odor).

Welsh et al. (1977) reported a statistically significant decrease in odor after drying swine manure. Zhang et al. (2009) stated that the odor intensity was affected by the initial moisture content. They compared the odor emission in the initial phase of composting of broiler litter with different moisture contents and found that nearly twice as much odor was emitted at the $75 \%$ moisture content compared to $40 \%$ moisture content in the first $24 \mathrm{~h}$.

\subsection{Microbial Count}

The results of the microbial analyses are shown in Table 4. High numbers of bacteria $\left(477 \times 10^{7}\right.$ cells $/ g$ manure) and yeast and mould cells (2700 cells/g manure) were found in the raw manure. The drying process reduced the number of bacteria by $65.62-99.83 \%$ (from
$477 \times 10^{7}$ to $164 \times 10^{7}-808 \times 10^{4}$ cells/g manure) and yeast and mold cells by $74.07 \%-99.63 \%$ (from 2700 cells/g manure to $700-<10$ cells/g manure). The drying process reduced the number of $E$. coli by $99.97 \%$ (from $21,986,666$ cells/g to $6263-<10$ cells/g manure). Salmonellae were detected in the raw manure and the dried manure samples of the $3 \mathrm{~cm}$ deep layer collected after drying at $40^{\circ} \mathrm{C}$. The results indicated that the higher the drying temperature and the thinner the manure layer, the greater the destruction of microorganisms in the dried manure.

Table 3. Odor rating.

\begin{tabular}{|c|c|c|}
\hline Parameter & Dried & Fresh \\
\hline Presence & $3.47 \pm 1.25$ & 10 \\
\hline Offensiveness & $3.07 \pm 1.53$ & 10 \\
\hline \multicolumn{3}{|l|}{ Description } \\
\hline Grain, Feed & 10 & - \\
\hline Mold, Musty & 6 & - \\
\hline Sour, Fermented & 4 & - \\
\hline Yeast & 2 & - \\
\hline Earth & 2 & - \\
\hline Fish & 2 & - \\
\hline Ammonia & 2 & 3 \\
\hline Sulphide, Rotten Egg & 2 & 12 \\
\hline Stagnant water & - & 12 \\
\hline Rotten Cabbage Mercaptans & - & 3 \\
\hline
\end{tabular}

* Total number of observations $=30$

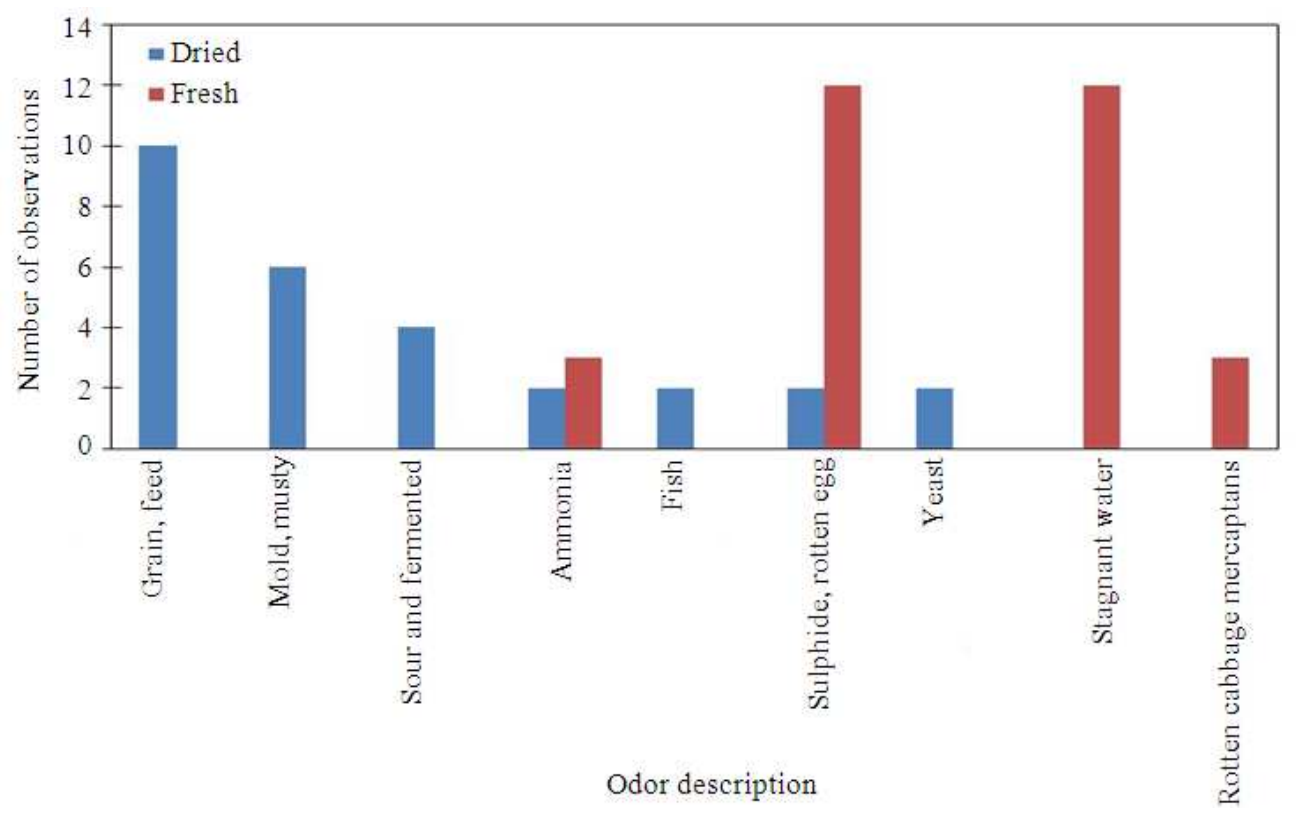

Fig. 4. Description of dried poultry manure odor. 
Table 4. Average Microbial count in raw and dried poultry manure.

\begin{tabular}{|c|c|c|c|c|c|}
\hline $\begin{array}{l}\text { Drying Temperature } \\
\left({ }^{\circ} \mathrm{C}\right)\end{array}$ & $\begin{array}{l}\text { Drying } \\
\text { Depth } \\
\text { (cm) }\end{array}$ & $\begin{array}{l}\text { Bacteria } \\
\left(10^{4} \text { cells } / \mathrm{g}\right)\end{array}$ & $\begin{array}{l}\text { Yeast/Mold } \\
\text { (cells/g) }\end{array}$ & $\begin{array}{l}\text { E. Coli } \\
\left(10^{4} \text { cells } / \mathrm{g}\right)\end{array}$ & $\begin{array}{l}\text { Salmonellae } \\
\text { (presence) }\end{array}$ \\
\hline \multirow[t]{3}{*}{40} & 1 & 55000 & 250 & 10 & $\mathrm{ND}^{\mathrm{b}}$ \\
\hline & 2 & 69000 & 370 & 20 & $\mathrm{ND}^{\mathrm{b}}$ \\
\hline & 3 & 75000 & 430 & 30 & $\mathrm{PP}^{\mathrm{a}}$ \\
\hline \multirow[t]{3}{*}{50} & 1 & 2100 & 170 & $<10$ & $\mathrm{ND}^{\mathrm{b}}$ \\
\hline & 2 & 2900 & 210 & 10 & $\mathrm{ND}^{\mathrm{b}}$ \\
\hline & 3 & 4100 & 310 & 20 & $\mathrm{ND}^{\mathrm{b}}$ \\
\hline \multirow[t]{3}{*}{60} & 1 & 440 & $<10$ & $<10$ & $\mathrm{ND}^{\mathrm{b}}$ \\
\hline & 2 & 530 & $<10$ & $<10$ & $\mathrm{ND}^{\mathrm{b}}$ \\
\hline & 3 & 620 & $<10$ & $<10$ & $\mathrm{ND}^{\mathrm{b}}$ \\
\hline Raw Manure & & 477000 & 2700 & 2290 & $\mathrm{PP}^{\mathrm{a}}$ \\
\hline
\end{tabular}

a- Partially Detected

b- Not Detected

Table 5. Protein content and $\mathrm{pH}$ of dried poultry manure.

\begin{tabular}{llll}
\hline $\begin{array}{l}\text { Drying } \\
\text { Temperature } \\
\left({ }^{\circ} \mathrm{C}\right)\end{array}$ & $\begin{array}{l}\text { Drying } \\
\text { Depth } \\
(\mathrm{cm})\end{array}$ & $\begin{array}{l}\text { Protein } \\
(\mathrm{mg} / \mathrm{kg})\end{array}$ & $\mathrm{pH}$ \\
\hline 40 & 1 & 40.66 & 6.6 \\
& 2 & 42.24 & 6.4 \\
50 & 3 & 42.39 & 6.6 \\
& 1 & 39.76 & 6.7 \\
60 & 2 & 41.96 & 6.7 \\
& 3 & 42.02 & 6.7 \\
& 1 & 39.48 & 6.6 \\
Raw Manure & 2 & 41.49 & 6.5 \\
\hline
\end{tabular}

The metabolic activity of an organism is the result of biochemical reactions, which are influenced by temperature. Consequently, the growth and survival of an organism is also influenced by temperature. The killing action of heat is a time-temperature dependent process (Gradel et al., 2003). Practical procedures by which heat is employed are divided into two categories: (a) moist heat and (b) dry heat. There is a considerable difference in the killing efficiency of moist and dry heat on organisms. Moist heat destroys microorganisms through denaturation of cellular proteins, facilitated by the presence of moisture. In contrast dry heat dehydrates the cell and destroys microorganisms through the oxidation of intracellular constituents (Cutter, 2002). Hence, dry heat (or hot air) sterilization is recommended where it is either undesirable or unlikely that pressurized steam will make direct and complete contact with material to be sterilized.

Chang et al. (1974) reported that the aerobic and anaerobic microbial counts were directly related to the moisture content of dehydrated cage layer samples and an inversely related to the dehydration temperature. The authors observed that the aerobic and anaerobic microbial counts could be significantly reduced if the moisture content of the sample was reduced to less than $10 \%$.

Kim et al. (2012) studied the thermal inactivation of Salmonellae in broiler litter by dry heat and found that the temperature and moisture content affected the survival of Salmonellae in the litter. They reported the time required for a $7 \log$ reduction in Salmonellae at 30\% moisture content to be 80,78 and 44 min for the 70,75 and $80^{\circ} \mathrm{C}$ drying conditions respectively. When the initial moisture content of the broiler litter was increased from 30 to $50 \%$, the time required to achieve a 7 log reduction was 100,93 and $63 \mathrm{~min}$ at 70,75 and $80^{\circ} \mathrm{C}$ drying temperatures, respectively.

Watcharasukarn et al. (2009) evaluated the efficiency of pathogen removal by dry heat in dairy manure. Their results indicated that $E$. coli was the most heat susceptible of the three organisms tested (E. coli, E. fecalis, C. perfringes) and sterilization (defined as a $10 \mathrm{log}$ reduction in viable cell count) times were found to be 5 $\mathrm{d}, 40 \mathrm{~min}$ and $10 \mathrm{~s}$ at 37,55 and $70^{\circ} \mathrm{C}$, respectively.

Elving (2009) observed a $3 \log$ reduction in the $E$. coli content of dairy manure after using dry heat for 60 $\min$ at $70^{\circ} \mathrm{C}$. The time needed for a $90 \%$ reduction in bacteria count was of $4.3,1.5$ and $0.5 \mathrm{~h}$ at 49,52 and $55^{\circ} \mathrm{C}$ respectively for Salmonellae.

\subsection{Manure $\mathbf{p H}$}

The manure $\mathrm{pH}$ dropped from 8.4 to about 6.9 during drying as shown in Table 5. The drying temperature and drying depth did not seem to have any significant effects on the $\mathrm{pH}$ of the dried manure. The reduction in the $\mathrm{pH}$ with time was due to the loss of ammonium through the volatization process. Similar results were also reported by other researchers. Lopez-Mosquera et al. (2008) observed a drop in $\mathrm{pH}$ (from 8.5-7.9) when drying poultry manure for pelletizing as fertilizer. Dikinya and Mufwanzala (2010) reviewed the literature and noticed lower $\mathrm{pH}$ values for dried poultry manure compared to initial values. Sistani et al. (2001) investigated the change in broiler litter $\mathrm{pH}$ after air drying, hot air drying $\left(65\right.$ and $\left.105^{\circ} \mathrm{C}\right)$ and freeze drying of broiler litter and observed that hot air drying at $105^{\circ} \mathrm{C}$ resulted in a significant drop in manure $\mathrm{pH}$. 


\subsection{Total Protein Content}

The results showed the total protein concentration of the dried manure was slightly lower than that of the raw manure (Table 5). Neither the temperature nore the depth of the manure layer appeared to have any significant effect on the final protein content.

Torto and Rhule (1997) reported a decrease in crude protein content $(27-20 \%)$ in poultry manure after both heated air drying $\left(80^{\circ} \mathrm{C}\right)$ and solar drying. Gihad (1976) reported a final crude protein content of $22.06 \%$ after forced air drying $\left(65^{\circ} \mathrm{C}\right)$ for the production of sheep feed. El-Deek et al. (2009) dried poultry manure at $80^{\circ} \mathrm{C}$ for the production of single cell protein and reported a final crude protein content of $19.10 \%$. Obasa et al. (2009) sun dried poultry manure for use as fish feed and reported a final protein content of $28.6 \%$. The protein contents of the dried poultry manure obtained in the present study are higher than the values reported in the literature, probably due to the lower drying temperatures used.

\subsection{Amino Acids Profile}

The amino acids profiles were determined on both the fresh and dried manure samples. The profiles consisted of 12 amino acids: alanine, glutamic, threonine, argninine, phenylalamine, valine, methionine, histidine, serine, leucine, lysine and cystine. The results are shown in Table 6. Are comparable to those reported by Vuori and Nasi (1977) and Cowieson et al. (2004) as shown in Table 7. In this study, 12 amino acids were analyzed in both the fresh and dried poultry manures. However, only 8 amino acids were analyzed by Flachowsky (1997) and Blair and Herone (1982) for dried poultry manure and 9 amino acids were analyzed by Zinn et al. (1996).

Generally, the drying process reduced the concentration of all amino acids in the poultry manure. Decreasing the ambient temperature and/or increasing the manure depth increased the concentration of amino acids in the dried manure. The highest values of amino acids were observed at the lowest drying temperature and the highest manure depth while the lowest values of amino acids were observed at the highest drying temperature and the lowest manure depth. Olivera-Castillo et al.
(2011) observed decreases in all amino acid contents at 48 and $70^{\circ} \mathrm{C}$ drying temperatures for cowpea. Wall et al. (1976) studied the effect of temperature on the amino acid profile of corn dried at temperatures between 15 and $143^{\circ} \mathrm{C}$ and found the majority of amino acids decrease in concentrations.

\subsection{Nutritional Value of Dried Poultry Manure}

The nutritional requirements for dairy and beef cows are shown in Table 8. Table 9 displays a comparison between the nutritional composition of the dried manure and commonly used forages in animal feeding.

\subsubsection{Energy}

Energy is defined as the ability or capacity to do work. Energy is essential for the maintenance of life processes including: cellular metabolism, growth, reproduction and physical activity. Animals derive energy through the catabolism of dietary carbohydrates, lipids and proteins within the body. The ability of a feed to supply energy is, therefore, of great importance in determining its nutritional value to animals. The mean gross energy values for carbohydrates, lipids and proteins have been estimated to be $17.2 \mathrm{~kJ} \mathrm{~g}^{-1}\left(4.1 \mathrm{kcal} \mathrm{g}^{-1}\right)$, $39.8 \mathrm{~kJ} \mathrm{~g}^{-1}\left(9.5 \mathrm{kcal} \mathrm{g}^{-1}\right)$ and $23.4 \mathrm{~kJ} \mathrm{~g}^{-1}\left(5.6 \mathrm{kcal} \mathrm{g}^{-1}\right)$, respectively (NRC, 1984). Providing the optimum energy level in the diet is important for the healthy development of animals. Excess dietary energy may result in high fat deposition, decreased feed intake and reduced weight gain, while a diet low in energy content may result in reduced weight gain as the animal utilize nutrients for energy provision rather than for the synthesis of new tissues and growth (Snow and Ghaly, 2007; NRC, 1984). The dried poultry manure had an energy content of $181.0 \mathrm{MJ} / \mathrm{kg}$ which meets the energy requirements of animals (32-37 MJ/kg). The energy content of the dried poultry manure compares well with those of blue grass $(180 \mathrm{MJ} / \mathrm{kg})$, birds food (180 $\mathrm{MJ} / \mathrm{kg})$ and wheat pasture $(187 \mathrm{MJ} / \mathrm{kg})$ and exceeds the energy contents of alfalfa $(157 \mathrm{MJ} / \mathrm{kg})$, timothy grass (167 $\mathrm{MJ} / \mathrm{kg}$ ) and orchard grass (170 MJ/kg).

Table 6. Effect of drying on amino acids concentration in manure.

\begin{tabular}{|c|c|c|c|c|c|c|c|c|c|c|c|c|c|c|}
\hline \multirow[b]{2}{*}{$\begin{array}{l}\text { Drying } \\
\text { Temperature } \\
\left({ }^{\circ} \mathrm{C}\right)\end{array}$} & \multirow[b]{2}{*}{$\begin{array}{l}\text { Drying } \\
\text { Depth } \\
\text { (cm) }\end{array}$} & \multirow[b]{2}{*}{$\begin{array}{l}\text { Total } \\
\text { Protein } \\
(\% \mathrm{db})\end{array}$} & \multicolumn{11}{|c|}{ Amino Acids $(\% \mathrm{db})$} & \multirow[b]{2}{*}{ Cystine } \\
\hline & & & Alanine & Glutamic & Threonine & Argninine & $\begin{array}{l}\text { Phenyl- } \\
\text { alamine }\end{array}$ & Valine & $\begin{array}{l}\text { Meth } \\
\text { ionine }\end{array}$ & Histidine & Serine & Leucine & Lysine & \\
\hline \multirow[t]{3}{*}{40} & 1 & 40.6 & 1.27 & 1.32 & 0.30 & 0.25 & 0.43 & 0.47 & 0.22 & 0.22 & 0.40 & 0.90 & 0.34 & 0.05 \\
\hline & 2 & 42.2 & 1.39 & 1.39 & 0.34 & 0.34 & 0.47 & 0.50 & 0.25 & 0.25 & 0.45 & 0.98 & 0.40 & 0.06 \\
\hline & 3 & 42.4 & 1.46 & 1.42 & 0.36 & 0.36 & 0.49 & 0.52 & 0.26 & 0.27 & 0.47 & 1.03 & 0.43 & 0.06 \\
\hline \multirow[t]{3}{*}{50} & 1 & 39.4 & 1.25 & 1.31 & 0.27 & 0.23 & 0.41 & 0.46 & 0.20 & 0.20 & 0.39 & 0.87 & 0.32 & 0.03 \\
\hline & 2 & 41.5 & 1.36 & 1.37 & 0.31 & 0.32 & 0.46 & 0.49 & 0.23 & 0.23 & 0.42 & 0.96 & 0.38 & 0.04 \\
\hline & 3 & 41.6 & 1.44 & 1.39 & 0.33 & 0.33 & 0.48 & 0.50 & 0.25 & 0.26 & 0.43 & 0.99 & 0.41 & 0.05 \\
\hline \multirow[t]{3}{*}{60} & 1 & 39.4 & 1.18 & 1.09 & 0.21 & 0.18 & 0.37 & 0.44 & 0.15 & 0.13 & 0.35 & 0.80 & 0.27 & 0.02 \\
\hline & 2 & 40.0 & 1.30 & 1.23 & 0.27 & 0.22 & 0.42 & 0.46 & 0.19 & 0.19 & 0.39 & 0.87 & 0.32 & 0.04 \\
\hline & 3 & 40.2 & 1.36 & 1.26 & 0.31 & 0.27 & 0.44 & 0.47 & 0.21 & 0.22 & 0.41 & 0.91 & 0.35 & 0.04 \\
\hline Raw Manure & & 43.3 & 1.52 & 1.47 & 0.39 & 0.39 & 0.52 & 0.54 & 0.29 & 0.31 & 0.50 & 1.11 & 0.47 & 0.07 \\
\hline
\end{tabular}


Table 7. Amino acid content in fresh and dried poultry wastes.

\begin{tabular}{|c|c|c|c|c|c|c|c|c|c|c|c|c|}
\hline \multirow[b]{2}{*}{ Poultry Wastes } & \multicolumn{11}{|c|}{ Amino Acids $(\% \mathrm{db})$} & \multirow[b]{2}{*}{ Cystine } \\
\hline & Alanine & Glutamic & Threonine & Argninine & $\begin{array}{l}\text { Phenyl- } \\
\text { alamine }\end{array}$ & Valine & Methionine & Histidine & Serine & Leucine & Lysine & \\
\hline Fresh Wastes & & & & & & & & & & & & \\
\hline Broiler Litter $^{\mathrm{a}}$ & 2.86 & 6.49 & 1.86 & 1.55 & 1.77 & 2.65 & 0.48 & 0.73 & 1.89 & 3.29 & 1.76 & 0.49 \\
\hline Poultry Manure ${ }^{b}$ & 0.53 & 1.04 & 0.36 & 0.26 & 0.28 & 0.34 & 0.11 & 0.13 & 0.43 & 0.44 & 0.28 & 0.00 \\
\hline Broiler Excreta ${ }^{c}$ & 1.01 & 2.56 & 0.96 & 0.96 & 0.84 & 1.20 & & 0.34 & 1.04 & 1.41 & 0.94 & \\
\hline Poultry Manure $^{\mathrm{d}}$ & 1.52 & 1.47 & 0.39 & 0.39 & 0.52 & 0.54 & 0.29 & 0.31 & 0.50 & 1.11 & 0.47 & 0.07 \\
\hline \multicolumn{13}{|l|}{ Dried Wastes } \\
\hline Poultry Litter & & & 0.90 & 0.40 & 0.70 & & 1.00 & 0.20 & & 1.20 & 1.00 & 0.00 \\
\hline Laver Manure & & & 1.00 & 0.70 & 0.70 & & 0.35 & 0.50 & & 0.70 & 1.10 & 0.40 \\
\hline Poultry Excreta ${ }^{\mathrm{f}}$ & & & 0.33 & 0.42 & 0.33 & 0.48 & 0.13 & 0.12 & 0.35 & 0.60 & 0.34 & \\
\hline Layer Waste ${ }^{\mathrm{g}}$ & & & 0.30 & 0.61 & $0.95^{\mathrm{j}}$ & 0.65 & $0.51^{\mathrm{i}}$ & 0.23 & & & 0.61 & $0.51^{\mathrm{i}}$ \\
\hline Layer Waste ${ }^{\mathrm{g}}$ & & & 0.00 & 0.40 & $0.63^{\mathrm{j}}$ & 0.52 & $0.78^{\mathrm{i}}$ & 0.19 & & & 0.39 & $0.78^{\mathrm{i}}$ \\
\hline Poultry Manure ${ }^{\mathrm{h}}$ & 1.36 & 1.96 & 0.31 & 0.27 & 0.44 & 0.47 & 0.21 & 0.22 & 0.41 & 0.91 & 0.35 & 0.04 \\
\hline
\end{tabular}

a- Broiler litter with peanut hull as bedding (Bhattacharya and Fontenot, 1965).

b- Fresh poultry manure, 10 amino acids assessed (Vuori and Nasi, 1977).

c- Fresh broiler excreta (Cowieson et al., 2004).

d- Fresh manure in present study.

e- Dried poultry manure, 8 amino acids assessed (Flachowsky, 1997).

f- Dehydrated poultry excreta, 9 amino acids assessed (Zinn et al., 1996).

g- Air and drum dried layer waste (Blair and Herron, 1982).

$\mathrm{h}$ - Dried poultry manure in present study $\left(60^{\circ} \mathrm{C}, 3 \mathrm{~cm}\right.$ depth $)$.

i- Reported as combined methionine and cyctine.

$\mathrm{j}$ - Reported as combined phenylalamine and tyrosine.

Table 8. Nutritional requirements for cows.

\begin{tabular}{lll}
\hline & Dairy Cow & Beef Cow $^{\mathrm{b}}$ \\
\hline Item & $220-230$ & \\
Total digestible matter $(\mathrm{g} / \mathrm{kg})$ & $32.7-33.9$ & 34.0 \\
Crude Fibertible energy $(\mathrm{gJ} / \mathrm{kg})$ & $120-340$ & \\
Crude Fat $(\mathrm{g} / \mathrm{kg})$ & $10-136$ & \\
Crude protein $(\mathrm{g} / \mathrm{kg})$ & $7.3-7.8$ & \\
Macroelements $(\mathrm{g} / \mathrm{kg})$ & & \\
Calcium & $0.6-2.2$ & $0.7-2.8$ \\
Chloride & $1.3-2.9$ & - \\
Magnesium & $1.3-2.0$ & 1.0 \\
Phosphorus & $2.5-3.8$ & $0.5-1.1$ \\
Potassium & $5.1-10.7$ & 6.5 \\
Sodium & $1.0-2.0$ & 0.8 \\
Cobalt & $0.10-0.11$ & 0.1 \\
Copper & 10 & 8.0 \\
Iodine & $0.4-0.5$ & 0.5 \\
Iron & 50 & 50.0 \\
Manganese & $13-40$ & 40.0 \\
Selenium & $1.5-3.0$ & 0.2 \\
Sulphur & $0.15-0.20$ & 0.1 \\
Zinc & $21-55$ & 30.0 \\
\hline
\end{tabular}

a: Combines nutritional requirements for maintenance and milk production for dairy cows (Ghaly et al., 2007).

b: (NRC, 1984).

\subsubsection{Carbohydrates}

Carbohydrates constitute the third most abundant group of organic molecules in the animal body. They are produced by photosynthetic plants and contain carbon, hydrogen and oxygen in the ratio of 1:2:1. Carbohydrates include sugars, starches, cellulose and other related compounds and serve as the principle source of metabolic en- ergy in terrestrial farm animals (NRC, 1984). Carbohydrates are included in animal diets because they are an inexpensive source of dietary energy and increase the feed palatability. The dried poultry manure had carbohydrate and crude fiber contents of 330 and $65 \mathrm{~g} / \mathrm{kg}$, respectively which exceed the recommended dietary intake for animals $(120-340 \mathrm{~g} / \mathrm{kg})$. However, the carbohydrate and fiber contents of the dried poultry manure are lower than all those of the forage crops $(180-310 \mathrm{~g} / \mathrm{kg})$.

\subsubsection{Crude Protein}

Proteins are high molecular weight organic compounds essential to the structure and formation of all living cells. They consist of amino acids joined by peptide bonds and are composed of 50-55\% carbon, $15-18 \%$ nitrogen, $20-23 \%$ oxygen, $6-8 \%$ hydrogen and $0-4 \%$ sulphur. Protein is required in the diet to provide essential amino acids and nitrogen for the synthesis of non-essential amino acids and other nitrogen containing compounds (Snow and Ghaly, 2007; NRC, 1984). Protein is typically the largest and most expensive component of an animal diet. The dried poultry manure had a protein content of $422 \mathrm{~g} / \mathrm{kg}$ which exceeds the recommended dietary intake of animals (7.3-7.8 g/kg). It also exceeds the protein contents of all the forage crops $(110-200 \mathrm{~g} / \mathrm{kg})$.

\subsubsection{Crude Fat}

Lipids (fats) are a heterogeneous group of organic compounds found in plant and animal tissues that are soluble in organic solvents such as benzene, chloroform and ether, but are only sparingly soluble in water. 
Table 9. Comparison of ingredients of dried poultry manure to those of commonly used field forages in feeding of cattle in North America.

\begin{tabular}{|c|c|c|c|c|c|c|c|c|}
\hline & \multirow[b]{2}{*}{ Item } & \multirow[b]{2}{*}{$\begin{array}{l}\text { Dried Poultry } \\
\text { Manure }\end{array}$} & \multicolumn{6}{|c|}{ Field Forage Crop } \\
\hline & & & Alfalfa & $\begin{array}{l}\text { Timothy } \\
\text { grass }\end{array}$ & $\begin{array}{l}\text { Blue } \\
\text { grass }\end{array}$ & $\begin{array}{l}\text { Birds } \\
\text { foot }\end{array}$ & $\begin{array}{l}\text { Orchard } \\
\text { grass }\end{array}$ & $\begin{array}{l}\text { Wheat } \\
\text { pasture }\end{array}$ \\
\hline Dry matter $(\%)$ & & & 24.0 & 26.0 & 36.0 & 36.0 & 24.0 & 21.0 \\
\hline Energy $(\mathrm{MJ} / \mathrm{kg})$ & & 181.000 & 157.0 & 167.0 & 180.0 & 180.0 & 170.0 & 187.0 \\
\hline Nutrients $(\mathrm{g} / \mathrm{kg})$ & Carbohydrates & 330.000 & 340.0 & 360.0 & 400.0 & 360.0 & 340.0 & 380.0 \\
\hline & Fiber & 65.000 & 270.0 & 310.0 & 270.0 & 270.0 & 300.0 & 180.0 \\
\hline & Protein & 422.000 & 190.0 & 110.0 & 150.0 & 150.0 & 140.0 & 200.0 \\
\hline & Fat & 63.000 & 30.0 & 38.0 & 39.0 & 39.0 & 40.0 & 40.0 \\
\hline \multicolumn{9}{|c|}{ Macroelements (g/kg) } \\
\hline & Calcium & 0.042 & 13.5 & 4.0 & 3.7 & 3.3 & 0.3 & 3.5 \\
\hline & Chlorine & 0.190 & 4.0 & 5.7 & 4.2 & 4.1 & 4.1 & 6.7 \\
\hline & Magnesium & 0.018 & & & & & & \\
\hline & Phosphorus & 0.010 & 2.7 & 2.8 & 3.0 & 3.0 & 3.0 & 3.6 \\
\hline & Potassium & 0.106 & 26.0 & 29.0 & 29.0 & 26.0 & 26.0 & 31.0 \\
\hline & Sodium & 0.043 & & & & & & \\
\hline \multicolumn{9}{|c|}{ Mircoelements $(\mathrm{mg} / \mathrm{kg})$} \\
\hline & Boron & 1.000 & & & & & & \\
\hline & Cobalt & 0.500 & & & & & & \\
\hline & Copper & 4.000 & & & & & & \\
\hline & Iodine & 0.500 & & & & & & \\
\hline & Iron & 4.000 & & & & & & \\
\hline & Manganese & 4.000 & & & & & & \\
\hline & Selenium & 0.114 & & & & & & \\
\hline & Sulfur & 200.000 & 2800 & 1500 & 1900 & 1900 & 2000 & 2200 \\
\hline & Zinc & 4.000 & & & & & & \\
\hline
\end{tabular}

Lipids are required for long-term storage of metabolic energy, to supply essential fatty acids and to carry fat soluble vitamins (NRC, 1984). Major classes of lipids include fatty acids, glycerol-derived lipids (including fats, oils and phospholipids) sphingosine-derived lipids (including ceramides, cerebrosides, gangliosides and sphingomye-lins, certain aromatic compounds, long chain alcohols and waxes. Fatty acids are long chain organic acids having the general formula $\mathrm{CH}_{3}\left(\mathrm{C}_{\mathrm{x}} \mathrm{H}_{\mathrm{y}}\right) \mathrm{COOH}$. The hydrocarbon chain is either saturated (only single bonds between adjacent carbon atoms) or unsaturated (double bonds between some of the adjacent carbon atoms) and usually contains an even number of carbon atoms $\left(C_{14}\right.$ to $\mathrm{C}_{24}$ ) in a straight chain. In nature, fatty acids usually occur as triesters of glycerol and are called triacylglycerols or triglycerides. Fatty acids are a major source of metabolic energy for animal growth, reproduction and milk production (NRC, 1984). The crude fat content of dried poultry manure is $63 \mathrm{~g} / \mathrm{kg}$ which meets the dietary requirements of animals $(10-136 \mathrm{~g} / \mathrm{kg})$. It is also higher than that of all the forage crops $(30-34 \mathrm{~g} / \mathrm{kg})$.

\subsubsection{Macroelements}

Macroelements are required by the body in relatively large amounts $(>100 \mathrm{mg} / \mathrm{kg}$ dry diet) and include calcium $(\mathrm{Ca})$, chlorine $(\mathrm{Cl})$, magnesium $(\mathrm{Mg})$, phosphorus $(\mathrm{P})$, potassium $(\mathrm{K})$ and sodium $(\mathrm{Na})$. These elements function in cellular metabolism, have important roles in osmoregulation and acid-base balance and serve as structural components of tissues (Jobling, 2001).

3.8.5.1. Calcium is an essential component of bone and cartilage and is necessary for the normal clotting of blood. Calcium is an activator for several enzymes including: pancreatic lipase, acid phosphatase, cholinesterase and succinic dehydrogenase. Calcium stimulates muscle contractions and regulates the transmission of nerve impulses. It also plays a key role in the regulation of cell membrane permeability and is essential for the adsorption of vitamin $B_{12}$ from the gastro-intestinal tract (NRC, 1984). The calcium content $(0.042 \mathrm{~g} / \mathrm{kg})$ of dried poultry manure is much lower than the dietary requirements of animals $(0.6-2.8 \mathrm{~g} / \mathrm{kg})$. It is also much lower than all those in the forage crops (3.3-12.5 g/ kg). Calcium deficient diets may cause rickets or osteomalacia, especially in dairy cows. Ground limestone can be used as a calcium supplement to increase calcium content of dried poultry manure used as a feed stuff (NRC, 1984). Also, citrus pulp can be used as a ruminant feed additive to increase the content of calcium in dried poultry manure (Arthington et al., 2002).

3.8.5.2. Chorine is the main monovalent anion of the extracellular fluid of the animal body. It is essential for the regulation of osmotic pressure and acid-base equilibrium. Chlorine also plays a role in the transport of oxygen and carbon dioxide in the blood and in the maintenance of digestive juice $\mathrm{pH}$ (NRC, 1984; 
Coppock, 1986). The chlorine content in dried poultry manure $(0.019 \mathrm{~g} / \mathrm{kg})$ is much lower than the dietary requirements of animals $(1.3-2.9 \mathrm{~g} / \mathrm{kg})$ and all those in the forage crops $(4-6.7 \mathrm{~g} / \mathrm{kg})$. Deficiencies in salts may result in muscle cramps and licking problems. Sodium chloride addition is an efficient and inexpensive method to increase both the chlorine and sodium content in dried poultry manure used as animal feed (NRC, 1984).

3.8.5.3. Magnesium has a number of biological functions. Like calcium, it is an essential component of bone and cartilage. Magnesium is an activator of several key enzyme systems including kinase and mutases, it stimulates muscle contractions and nerve impulses, is involved in the regulation of intracellular acid-base balance and plays an important role in carbohydrate, protein and lipid metabolism (NRC, 1984). The magnesium content of the dried poultry manure $(0.018$ $\mathrm{g} / \mathrm{kg}$ ) is much lower than the dietary requirements of animals (0.13-0.20 g/kg). Magnesium deficiency in cattle may cause tetancy. Magnesium oxide can be used to increase the magnesium content of the dried poultry manure used as animal feed (NRC, 1984).

3.8.5.4. Phosphorus phosphorus has several biological functions. Like calcium and magnesium, phosphorus in as essential component of bone and cartilage. It is an essential component of phospholipids, nucleic acids and high energy phosphate esters (ATP, ADP, AMP). Inorganic phosphate also helps to regulate the acid-base balance of animal body fluids (NRC, 1984). The phosphorus content of the dried poultry manure $(0.010$ $\mathrm{g} / \mathrm{kg}$ ) is much lower than the dietary requirements of animals $(0.5-3.8 \mathrm{~g} / \mathrm{kg})$ and the phosphorus levels in all forage crops $(2.7-3.6 \mathrm{~g} / \mathrm{kg})$. Phosphorus deficiencies may cause decreased growth rates and feed conversion as well as pica (NRC, 1984). Dicalcium phosphate of mustard cake oil can be used to increase the phosphorus content of dried poultry manure used as animal feed (Rahman et al., 2009).

3.8.5.5. Potassium is the major cation of the intracellular fluid in the animal body. It is responsible for the regulation of intracellular osmotic pressure and acid-base equilibrium. It stimulates muscle contraction and is required for glycogen and protein synthesis and the metabolic breakdown of glucose (NRC, 1984). The potassium content of the dried poultry manure $(0.106$ $\mathrm{g} / \mathrm{kg}$ ) is much lower than the dietary requirements of animals $(5.1-10.7 \mathrm{~g} / \mathrm{kg}$ ) and the phosphorus content of all the forage crops $(26-31 \mathrm{~g} / \mathrm{kg})$. Potassium deficiency may cause weight loss, weakness, tetany and paralysis (NRC, 1984). Citrus pulp can be used as a ruminant feed additive to increase the content of potassium in dried poultry manure used as animal feed (Arthington et al., 2002).
3.8.5.6. Sodium is the main monovalent cation of the extracellular fluids in the animal body. Its principal function is the regulation of osmotic pressure and the maintenance of acid-base equilibrium. Sodium also has an effect on muscle contraction and plays a role in the absorption of carbohydrates (NRC, 1984). The sodium content in dried poultry manure $(0.043 \mathrm{~g} / \mathrm{kg})$ is much lower than the dietary requirements for animals (0.8-2.0 $\mathrm{g} / \mathrm{kg}$ ). Deficiencies in salt may cause muscle cramping and licking in cattle. Sodium chloride can be used as an effective and inexpensive supplement for both sodium and chloride to increase the nutritional value of a dried poultry manure used as animal feed (NRC, 1984).

\subsubsection{Microelements}

Microelements are required by the body in trace amounts $(<100 \mathrm{mg} / \mathrm{kg}$ dry dies) and include boron (B), copper $(\mathrm{Cu})$, iron $(\mathrm{Fe})$, manganese $(\mathrm{Mn})$, molybdenum (Mo), selenium (Se), zinc ( $\mathrm{Zn}$ ) and sulphur (S) (NRC, 1984). Microelements are involved in the regulation of cellular metabolism and are required for proper growth and development. There are no reported values for the micronutrient content of common field forage crops.

3.8.6.1. Cobalt is an essential component of Vitamin B12 synthesis by ruminal bacteria and is thus involved in many enzyme systems of the digestive tract and liver. The cobalt content in dried poultry manure $(0.5 \mathrm{mg} / \mathrm{kg})$ is higher than the dietary requirements for animals (0.1-0.11 $\mathrm{mg} / \mathrm{kg}$ ). Excess cobalt is not known to show toxic effects until consumption levels reach 300-1000 times the required levels (30 mg/kg) (NRC, 1984).

3.8.6.2. Copper is an essential component of numerous oxidation-reduction systems. It is involved in iron metabolism, haemoglobin synthesis and red blood cell production and maintenance. Copper is also necessary for the formation of the pigment melanin, bone and connective tissue and for maintaining the integrity of the myelin sheath of nerve fibers. The copper content in dried poultry manure $(4 \mathrm{mg} / \mathrm{kg})$ is lower than the dietary requirement for animals $(8-10 \mathrm{mg} / \mathrm{kg})$. Low dietary copper levels can lead to lack of pigmentation, decreased tyrosinase production, myocardium fibrosis, thinning of bones, decreased collagen cross linking and increased fracture rate (NRC, 1984). Citrus pulp can be used as a ruminant feed additive to increase the content of copper in dried poultry manure used as animal feed (Arthington et al., 2002).

3.8.6.3. Iodine is an essential component of numerous metabolic regulatory pathways through its incorporation in thyroid hormones. It is involved in thermoregulation, metabolism, reproduction, growth and development. The 
iodine content of dried poultry manure $(0.5 \mathrm{mg} / \mathrm{kg})$ meets the dietary requirements of animals $(0.4-0.5 \mathrm{mg} / \mathrm{kg})$ (NRC, 1984).

3.8.6.4. Iron is an essential component of the respiratory pigments haemoglobin and myoglobin and is necessary for oxygen and electron transport within the body. It is also an essential component of several enzyme systems including cytochromes, catalases, peroxidases, oxidases and dehydrogenases. The iron content of dried poultry manure $(4 \mathrm{mg} / \mathrm{kg})$ is much lower than the dietary requirements of animals $(50 \mathrm{mg} / \mathrm{kg})$. Iron deficiency may result in reduced haemoglobin production, reduced packed cell volume, reduced saturation of transferring, listlessness, pale mucus membranes, reduced food consumption and decreased weight gain (NRC, 1984). Citrus pulp can be used as a ruminant feed additive to increase the content of iron in dried poultry manure used as animal feed (Arthington et al., 2002).

3.8.6.5. Manganese is an activator of enzymes responsible for phosphate group transfer including phosphate transferases and phosphate dehydrogenases. Manganese is a component or a cofactor of several key enzyme systems and as such is essential for bone formation, the regeneration of red blood cells, carbohydrate and lipid metabolism and the reproductive cycle. The manganese content of dried poultry manure (4 $\mathrm{mg} / \mathrm{kg}$ ) is lower than the dietary requirements of animals $(13-40 \mathrm{mg} / \mathrm{kg})$. Deficiencies in manganese may result in decreased reproductive abilities in cattle (NRC, 1984). Amino acid complexed manganese can be used as a additive to increase the manganese content of dried poultry manure used as animal feed (Nocek et al., 2006).

3.8.6.6. Selenium is an essential component of the enzyme glutathione peroxidase and as such serves to protect cellular tissues and membranes against oxidative damage. It is involved in the synthesis of ubiquinone and as such is involved in cellular electron transport. It also influences the absorption and retention of vitamin $\mathrm{E}$. The selenium content of dried poultry manure $(0.114 \mathrm{mg} / \mathrm{kg})$ is much lower than the dietary requirement of animals $(1.5-3 \mathrm{mg} / \mathrm{kg})$. Low selenium levels may result in white muscle disease (white muscle, heart failure and paralysis) and depression of glutathione peroxidase (NRC, 1984). Se-yeast may be used to increase the selenium content of dried poultry manure used as animal feed (Gressley, 2009).

3.8.6.7. Sulphur is an essential component of the amino acids methionine and cysteine, the vitamins thiamine and biotin and the hormone insulin. It also plays a role in several key enzyme systems (NRC, 1984). The sulphur content of dried poultry manure $(200 \mathrm{mg} / \mathrm{kg})$ exceeds the dietary requirements of animals (0.1-0.2 $\mathrm{mg} / \mathrm{kg})$. However, the sulphur content of dried poultry manure is much lower than the sulphur content of all forage crops $(1500-2800 \mathrm{mg} / \mathrm{kg})$. Excess sulphur consumption may result in restlessness, diarrhoea, muscular twitching, shortness of breath and death (NRC, 1984).

3.8.6.8. Zinc serves as a component or cofactor of many important enzymes systems and thus plays an important role in carbohydrate, lipid and protein metabolism. It is also involved in the synthesis and metabolism of nucleic acids and plays a role in wound healing. The zinc content of dried poultry manure $(4 \mathrm{mg} / \mathrm{kg}$ ) was much lower than the dietary requirement of animals (21-30 mg/kg). Zinc deficiency may result in listlessness, swollen feet and dermatitis, vision impairment, excess salivation decreased rumen and improper wound healing (NRC, 1984). Citrus pulp can be used as a ruminant feed additive to increase the content of zinc in dried poultry manure used as animal feed (Arthington et al., 2002).

\subsection{Feeding of Poultry Manure}

Poultry manure has been the focus of feeding to ruminants due to the fact that it is high in nitrogen, which ruminants can utilize as an energy source (Fedler et al., 1985). Raw poultry manure consists of $70 \%$ water and $3.5 \%$ nitrogen (Nicholson et al., 1996). The ammonium fraction increases with storage, due to the decomposition of organic nitrogen and may be lost by volatilization.

Boer (1981) indicated that the results of a series of digestibility experiments on dried poultry manure feeding to ruminants showed an average net energy content of about $6400 \mathrm{~kJ} / \mathrm{kg}$ dried manure and an average protein content of about $300 \mathrm{~g} / \mathrm{kg}$ dried manure. Feeding experiments with young fattening bulls showed that the dried poultry manure can be used in fattening rations without altering significantly the daily grain, feed-conversion, carcass-quality, or taste and smell of meat.

Thomas et al. (1972) reported that feeding caged layer waste to dairy cattle did not affect the composition or flavour of milk.

Vezey and Dobbins (1975) conducted uncontrolled tests to determine the palatability of different mixtures consisting of different levels of ground corn, poultry floor litter, cage layer manure, dried molasses, water and lactobacillus acidophilius culture that were fed to Holstien steers. The results indicated that all mixtures appeared to be equally palatable.

Torto and Rhule (1997) investigated the effect adding dried poultry manure to the diet of West African Dwarf goats. Six goats were placed on each of the four experimental diets which consisted of (a) 100\% straw, (b) $60 \%$ straw, $40 \%$ molasses, (c) $50 \%$ straw, $40 \%$ molasses, 
$10 \%$ dried poultry manure and (d) $40 \%$ straw, $40 \%$ molasses and $20 \%$ dried poultry manure. Goats placed on diet (c) and (d) were found to have the greatest weight gains through the study and greater feed efficiency than those on diet (a) and (b).

Okeudo and Adegbola (1993) investigated the effect of replacing a traditional protein supplement (ground nut cake and wheat offal) with dried poultry manure at a rate of $0,13,25,35$ and $45 \%$ over a 104 day period in West African Dwarf goats. They observed no statistically significant differences in growth rates on any of the diets and concluded that dried poultry manure protein is used as efficiently as traditional protein supplements.

Obeidat et al. (2011) evaluated the effect of adding broiler litter to the diet of Awassi lambs at a rate of 0,100 and $200 \mathrm{~g} / \mathrm{kg}$ diet for 70 days. It was reported that no net difference in weight gain or dry matter intake was created by the three diets. Meat quality however increased due to a linear decrease of both subcutaneous and total fat with the addition of broiler litter to the lambs' diet. Color evaluation indicated an increase in whiteness and a decrease in redness in the meat of the lambs fed broiler litter. There was no change in meat $\mathrm{pH}$, shear force, water holding capacity, or cooking loss between the three diets.

\section{CONCLUSION}

Dried poultry manure contained sufficient levels of digestible energy, crude fiber, protein and fat, cobalt and iodine. Although dried poultry manure did not meet the dietary requirements for calcium, chloride, magnesium, phosphorus, potassium, sodium, copper, iron, manganese, selenium, sulphur or zinc it could be used as a feed stuff for ruminants after supplementation with the required nutrients. Heated air drying was most efficient at $60^{\circ} \mathrm{C}$ and at a depth of $3 \mathrm{~cm}$. During drying poultry manure decreased in $\mathrm{pH}$ (8.4-6.9), protein content $(43 \%$ to $39-43 \%)$ and amino acid content. The greatest reductions in microbial population occurred at the highest drying temperature $\left(60^{\circ} \mathrm{C}\right)$ and the lowest manure depth $(1 \mathrm{~cm})$. Reductions in the number of bacteria, mold/ yeast and E.coli were 65-99, 74-99 and $99.97 \%$ respectively, Salmonellae was not detected in the dried product. Dried poultry manure was found to have a non-offensive odor. Odor intensity and offensiveness were reduced by 65 and $69 \%$ respectively during drying. Thin layer heated air drying of poultry manure between 40 and $60^{\circ} \mathrm{C}$ created a safe and nutritionally appropriate feed for ruminants.

\section{ACKNOWLEDGEMENT}

This research was funded by the Natural Science and Engineering Research Council (NSERC) of Canada.

\section{REFERENCES}

Akal, D., K. Kahveci and A. Cihan, 2007. Mathematical modelling of drying of rough rice in stacks. Food Sci. Technol. Int., 13: 437-445. DOI: 10.1177/1082013207087814

Alam M.S., M. J. Khan, M.A. Akber and M. Kamruzzaman, 2008. Broiler litter and layer manure in the diet of growing bull calves. Bangladesh Vet., 25: 62-67. DOI: 10.3329/bvet.v25i2.4619

Amine-Khodja, A., C. Richard, B. Lavedrine, G. Guyot and O. Trubetskaya et al., 2006. Water-soluble fractions of composts for the photodegradation of organic pollutants in solar light. Environ. Chem. Lett., 3: 173-177. DOI: $10.1007 / \mathrm{s} 10311-005-0028-8$

Amon, B., V. Kryvoruchko, T. Amon and S. Zechmeister-Boltenstern, 2006. Methane, nitrous oxide and ammonia emissions during storage and after application of dairy cattle slurry and influence of slurry treatment. Agric. Ecosyst. Environ., 112: 153-162. DOI: $10.1016 /$ j.agee.2005.08.030

AOAC, 2011. Official Methods of Analysis. 18th Edn., Association of Official Agricultural Chemists, Gaithersburg, MD, USA., ISBN: 978-0935584783.

APHA, 1980. Standard Methods for Examination of water and Wastewater. 1st Edn., American Public Health Association. Washington, DC. USA., ISBN: 0875530915.

Arthington, J.D., W.E. Kunkle and A.M. Martin, 2002. Citrus pulp for cattle. Vet. Clin. North Am. Food Anim. Pract., 18: 317-326. PMID: 12235663

ASABE, 2009. Standards. American Society of Agricultural and Biological Engineers. 1st Edn., Saint Joseph, MI. USA., ISBN-10: 87551187.

Axtell, R.C., 1999. Poultry integrated pest management: Status and future. Integ. Pest Manage. Rev., 4: 53-73. DOI: 10.1023/A:1009637116897

Benali, M. and T. Kudra, 2002. Thermal dewatering of diluted organic suspensions: Process mechanism and drying kinetics. Dry. Technol.: Int. J., 20: 935-951. DOI: 10.1081/DRT-120003770

Bernhart, M. and O.O. Fasina, 2009. Moisture effect on the storage, handling and flow properties of poultry litter. Waste Manage., 29: 1392-1398. PMID: 18990556

Berry, E.D. and D.N. Miller, 2005. Cattle feedlot soil moisture and manure content. J. Environ. Q., 34: 656-663. DOI: $10.2134 /$ jeq2005.0656

Bhattacharya, A.N. and J.P. Fontenot, 1965. Utilization of different levels of poultry litter nitrogen by sheep. J. Anim. Sci., 24: 1174-1178.

Blair, R. and K.M. Herron. 1982. Growth performance of broilers fed on diets containing processed poultry wastes. Br. Poultry Sci., 23: 279-287. DOI: 10.1080/00071688208447959 
Boer, A.J.D., 1981. Socioeconomic aspects of dairying in developing countries. J. Dairy Sci., 64: 2453-2462. DOI: $10.3168 /$ jds.S0022-0302(81)82870-6

Brooks, M.S., N.H.A. El-Hana and A.E. Ghaly, 2008. Effects of tomato geometries and air temperature on the drying behavior of plum tomato. Am. J. Applied Sci., 5: 1369-1375. DOI: 10.3844/ajassp.2008.1369.1375

Chang, T.S., D. Dorn and H.C. Zindel, 1974. Stability of poultry anaphage. Poult. Sci., 53: 2221-2224. DOI: $10.3382 /$ ps.0532221

Coppock, C.E., 1986. Mineral utilization by the lactating cow-chlorine. J. Dairy Sci., 69: 595-603. DOI: 10.3168/jds.S0022-0302(86)80444-1

Cowieson, A.J., T. Acamovic and M.R. Bedford, 2004. The effects of phytase and phytic acid on the loss of endogenous amino acids and minerals from broiler chickens. Br. Poult. Sci., 45: 101-108. DOI: 10.1080/00071660410001668923

Cutter, C.N., 2002. Microbial control by packaging: A review. Crit. Rev. Food Sci. Nutr., 42: 151-161. DOI: 10.1080/10408690290825493

Dikinya, O. and N. Mufwanzala, 2010. Chicken manure-enhanced soil fertility and productivity: Effects of application rates. J. Soil Sci. Environ. Manage., 1: 46-54.

El-Deek, A.A., K.M. Ghonem, S.M. Hamdy, M.A. Aser and F.M. Aljassas et al., 2009. Producing single cell protein from poultry manure and evaluation for broiler chickens diets. Int. J. Poult. Sci., 8: 1062-1077.

El-Sayed, H.S., 1993. Solar drying of poultry manure for animal feed under simulated Egyptian conditions. Unpublished Ph.D. Thesis, Cairo University, Giza, Egypt.

Elving, J., 2009. Pathogenic inactivation and regrowth in organic waste during biological treatment. Ph.D. Thesis, Swedish University of Agricultural Sciences, Uppsala, Sweden.

Ertekin, C. and O. Yaldiz, 2004. Drying of eggplant and selection of a suitable thin layer drying model. J. Food Eng., 63 : 349-359. 10.1016/j.jfoodeng.2003.08.007

FAO, 2010. Agricultural Handbook: Poultry Meat and Eggs. 1st Edn., FAO Investment Centre Division, Rome Italy.

Fares, F., A. Albalkhi, J. Dec, M.A. Bruns and J.M. Bollag, 2005. Physicochemical characteristics of animal and municipal wastes decomposed in arid soils. J. Environ. Q., 34: 1392-1403. PMID: 15998862

Fedler, C.B., L.L. Berger, G.R. Hrubant and D.L. Day, 1985. High-rate ensiling of corn and manure for feed. Proceeding from the Winter Meeting of the American Society of Agricultural Engineers, Dec. 11-11, New Orleans, LA, USA.
Flachowsky, G., 1997. Animal excreta as feedstuff for ruminants-a review. J. Applied Anim. Res., 12: 1-40. DOI: 10.1080/09712119.1997.9706185

Gely, M.C. and E.M. Santalla, 2007. Moisture diffusivity in quinoa (Chenopodium quinoa Willd.) seeds: Effect of air temperature and initial moisture content of seeds. J. Food Eng., 78: 1029-1033. DOI: 10.1016/j.jfoodeng.2005.12.015

Ghaly, A.E. and K.N. MacDonald, 2012. Kinetics of thin layer drying of poultry manure. Am. J. Biochem. Biotechnol.

Ghaly, A.E., H.A. Farag and M. Verma, 2007. A hydroponic system for purification of anaerobically treated dairy manure and production of wheat as a nutritional forage crop. Am. J. Agric. Biol. Sci., 2: 206-217. DOI: 10.3844/ajabssp.2007.206.217

Gihad, E.A., 1976. Value of dried poultry manure and urea as protein supplements for sheep consuming low quality tropical hay. J. Anim. Sci., 42: 705-709.

Gradel, K.O., J.C. Jorgensen, J.S. Andersen and J.E.L. Corry, 2003. Laboratory heating studies with Salmonella spp. and Escherichia coli in organic matter, with a view to decontamination of poultry houses. J. Applied Microbiol., 94: 919-928. DOI: 10.1046/j.1365-2672.2003.01933.x

Gressley, T.F., 2009. Zinc, copper, manganese and selenium in dairy cattle rations. Proceedings of the 7th Annual Mid-Atlantic Nutrition Conference, (AMANC' 09), University of Maryland, College Park, MD, USA., pp: 65-71.

Jobling, M., 2001. Food composition and analysis in Houlihan, D., T. Boujard and M. Jobling, 2001. Food Intake in Fish. 1st Edn., Blackwell Science Ltd. Malden, MA., ISBN-10: 0632055766, pp: 448.

Kim, J., J. Diao, M.W. Shepherd Jr., R. Singh and S.D. Heringa et al., 2012. Validating thermal inactivation of Salmonella spp. in fresh and aged chicken litter. Applied Environ. Microbiol., 78: 1302-1307. DOI: 10.1128/AEM.06671-11

Lay, D.C. Jr., R.M. Fulton, P.Y. Hester, D.M. Karcher and J.B. Kjaer et al., 2011. Hen welfare in different housing systems. Poult. Sci., 90: 278-294. DOI: 10.3382/ps.2010-00962

Leonard, A., S. Blacher, P. Marchot, J. P. Pirard and M. Crine, 2005. Convective drying of wastewater sludges: influence of air temperature, superficial velocity and humidity on the kinetics. Dry. Technol.: Int. J., 23: 1667-1679. DOI: 10.1081/DRT-200065082

Loehr, R.C., 1977. Food, Fertilizer and Agricultural Residues. 1st Edn., Ann Arbor Science Publishers, ISBN-10: 0250401908, pp: 727.

Lopez-Mosquera, M.E., F. Cabalerio, M.J. Sainz, A. Lopes-Fabal and E. Carral, 2008. Fertilizing value of broiler litter: Effects of drying and pelletizing. Bioresource Technol., 99: 5626-5633. DOI: 10.1016/j.biortech.2007.10.034 
Martens, W. and R. Bohm, 2009. Overview of the ability of different treatment methods for liquid and solid manure to inactivate pathogens. Bioresource Technol., 100: 5374-5378. DOI: 10.1016/j.biortech.2009.01.014

Maskan, A., S. Kaya and M. Maskan, 2002. Hot air and sun drying of grape leather (pestil). J. Food Eng., 54: 81-88. DOI: 10.1016/S0260-8774(01)00188-1

Nazghelichi, T., M.H. Kianmehr and M. Aghbashlo, 2010. Thermodynamic analysis of fluidized bed drying of carrot cubes. Energy, 35: 4679-4684. DOI: 10.1016/j.energy.2010.09.036

Nicholson, F.A., B.J. Chambers and K.A. Smith, 1996. Nutrient composition of poultry manures in England and Wales. Bioresource Technol., 58: 279-284. DOI: 10.1016/S0960-8524(97)86087-7

Nocek, J.E., M.T. Socha and D.J. Tomlinson, 2006. The effect of trace mineral fortification level and source on performance of dairy cattle. J. Dairy Sci., 89: 2679-2693. DOI: 10.3168/jds.S0022-0302(06)72344-X

NRC, 1984. Nutrient Requirements of Beef Cattle. 6th Edn., National Academy Press, Washington D.C., USA., pp: 90.

Obasa, S.O., W.O. Alegbeleye and J.B. Amole, 2009. Dried poultry manure meal as a substitute for soybean meal in the diets of African catfish (Clarias gariepinus) (Burchell 1822) advanced fry. Turkish J. Fisheries Aquatic Sci., 9: 121-124.

Obeidat, B.S., M.S. Awawdeh, A.Y. Abdullah, M.M. Muwulla and M.A. Abu Ishmais et al., 2011. Effects of feeding broiler litter on performance of Awassi lambs fed finishing diets. Anim. Feed Sci. Technol., 165: 15-22. DOI: 10.1016/j.anifeedsci.2011.02.007

Okeudo, N.J. and A.A. Adegbola, 1993. Utilisation of dried caged-hen manure and cassava peels for intensive sheep production. Tropical Anim. Health Product., 25: 234-238. DOI: 10.1007/BF02250877

Olivera-Castillo, L., M. Pino-Aguilar, M. Lara-Flores, S. Granados-Puerto and J. Montero-Muñoz et al., 2011. Substitution of fish meal with raw or treated cowpea (Vigna unguiculata L Walp, IT86-D719) meal in diets for Nile tilapia (Oreochromis niloticus L.) fry. Aquaculture Nutr., 17: e101-e111. DOI: 10.1111/j.1365-2095.2009.00739.x

Onider, G.O., T.J. Siebenmorgen and A. Mauromoustakos, 2010. Low-temperature, low-relative humidity drying of rough rice. J. Food Eng., 100: 545-550. DOI: 10.1016/j.jfoodeng.2010.05.004

Panchariya, P.C., D. Popovic and A.L. Sharma, 2002. Thin-layer modelling of black tea drying process. J. Food Eng., 52: 349-357. DOI: 10.1016/S0260-8774(01)00126-1

Rahman, M.A., Z.H. Khandaker and A.B.M. Khaleduzzaman, 2009. Bioavailability of phosphorus and its effect on the nutrient utilization in cattle. Bangladeshi J. Anim. Sci., 38: 33-41. DOI: 10.3329/bjas.v38i1-2.9910
Rao, P.S., S. Bal, T.K. Goswami, 2007. Modelling and optimization of drying variables in thin layer drying of parboiled paddy. J. Food Eng., 78: 480-487. DOI: 10.1016/j.jfoodeng.2005.10.019

Sistani, K., D. Miles, D. Rowe, G. Brink and S. McGowen, 2001. Impact of drying method, dietary phosphorus levels and methodology on phosphorus chemistry of broiler manure. Commun. Soil Sci. Plant Anal., 32: 2738-2793.

Snow, A.M. and A.E. Ghaly, 2007. The nutrition value of wastewater grown barley and it's utilization in fish feed. Am. J. Agric. Biol. Sci., 2: 168-183. DOI: 10.3844/ajabssp.2007.159.167

Thomas, J.W., Y. Yu, P. Tinnimitt and H.C. Zindel, 1972. Dehydrated poultry waste as a feed for milking cows and growing sheep. J. Dairy Sci., 55: 1261-1265. DOI: 10.3168/jds.S0022-0302(72)85659-5

Torto, R. and S.W.A. Rhule, 1997. Performance of West African dwarf goats fed dehydrated poultry manure as a dry season supplement. Tropical Anim. Health Prod., 29: 180-184. DOI: 10.1007/BF02633020

Vezey, S.A. and C.N. Jr. Dobbing. 1975. Ensiling poultry litter, cage layer manure. In: Managing Livestock Wastes. Proceedings of the 3rd International Symposium on Livestock Waste. American Society of Agricultural Engineers. St. Joseph, Michigan, ASAE Publishing, 195-196. ISBN: 0916150003

Vuori, A.T. and J.M. Nasi, 1977. Fermentation of poultry manure for poultry diets. Br. Poult. Sci., 18: 257-264. DOI: $10.1080 / 00071667708416361$

Wall, J.S., C. James and G.L. Donaldson, 1976. Corn proteins: Chemical and physical changes during drying of grain. Cereal Chem., 52: 779-790.

Watcharasukarn, M., P. Kaparaju, J.P. Steyer, K.A. Krogfelt and I. Angelidaki, 2009. Screening Escherichia coli, Enterococcus faecalis and Clostridium perfringens as Indicator Organisms in Evaluating Pathogen-Reducing Capacity in Biogas Plants. Environ. Microbiol., $\quad 58$ : 221-30. DOI: 10.1007/s00248-009-9497-9

Welsh, F.W., D.D. Schulte, E.J. Kroeker and H.M. Lapp, 1977. The effect of anaerobic digestion upon swine manure odors. Canadian Agric. Eng., 19: 122-126.

Zhang, W. and A. Lau, 2007. Reducing ammonia emission from poultry manure composting via struvite formation. J. Chem. Technol. Biotechnol., 82: 598-602. DOI: $10.1002 /$ jctb. 1701

Zhang, W., A. K. Lau and Z. S. Wen. 2009. Preventive control of odor emissions through manipulation of operational parameters during the active phase of composting. J. Environ. Sci. Health, Part B: Pesticides, Food Contaminants Agric. Wastes, 44: 496-505. DOI: 10.1080/03601230902935451

Zinn, R.A., R. Barajas, M. Montano and Y. Shen, 1996. Protein and energy value of dehydrated poultry excreta in diets for feedlot cattle. J. Anim. Sci., 74: 2331-2335. PMID: 8904699 